\title{
A comparison of rapid point-of-care tests for the detection of avian influenza A(H7N9) virus, 2013
}

C Baas ${ }^{1,2}$, I G Barr ${ }^{1,2}$, R A Fouchier ${ }^{3}$, A Kelso ${ }^{1}$, A C Hurt (aeron.hurt@influenzacentre.org) ${ }^{1,2}$

1. World Health Organization Collaborating Centre for Reference and Research on Influenza, Victorian Infectious Diseases Reference Laboratory (VIDRL), Melbourne, Victoria, Australia

2. Monash University, School of Applied Sciences, Churchill, Victoria, Australia

3. Department of Viroscience, Erasmus MC, Rotterdam, the Netherlands

Citation style for this article:

Baas C, Barr IG, Fouchier RA, Kelso A, Hurt AC. A comparison of rapid point-of-care tests for the detection of avian influenza A(H7N9) virus, 2013. Euro Surveill. 2013;18(21):pii=20487. Available online: http://www.eurosurveillance.org/ViewArticle.aspx?Articleld=20487

Article submitted on 21 May 2013 / published on 23 May 2013

Six antigen detection-based rapid influenza point-ofcare tests were compared for their ability to detect avian influenza $A\left(\mathrm{H}_{7} \mathrm{~N} 9\right)$ virus. The sensitivity of at least four tests, standardised by viral infectivity (TCID ${ }_{50}$ ) or RNA copy number, was lower for the influenza $A\left(\mathrm{H}_{7} \mathrm{~N}_{9}\right)$ virus than for seasonal $A\left(\mathrm{H}_{3} \mathrm{~N}_{2}\right), A\left(\mathrm{H}_{1} \mathrm{~N}_{1}\right)$ pdmog or other recent avian $\mathrm{A}\left(\mathrm{H}_{7}\right)$ viruses. Comparing detection limits of $\mathrm{A}\left(\mathrm{H}_{7} \mathrm{~N} 9\right)$ virus with $\mathrm{Ct}$ values of $\mathrm{A}\left(\mathrm{H}_{7} \mathrm{~N}_{9}\right)$ clinical specimens suggests the tests would not have detected most clinical specimens.

Human infections with influenza viruses derived directly from wild birds or poultry are relatively rare, although since 2003, over 600 human infections with influenza $\mathrm{A}\left(\mathrm{H}_{5} \mathrm{~N}_{1}\right)$ viruses have been detected, many of which were fatal [1]. During the same period, a small number of influenza $\mathrm{A}\left(\mathrm{H}_{7}\right)$ virus infections worldwide have also occurred in humans upon contact with infected poultry, generally resulting in mild symptoms such as conjunctivitis with occasional respiratory involvement and one death [2-4]. In contrast, China announced in March 2013 human infections with a novel reassortant avian influenza $\mathrm{A}\left(\mathrm{H}_{7} \mathrm{~N} 9\right)$ virus which caused severe pneumonia resulting in a number of deaths [5]. Cases have occurred predominantly in men over 60 years of age living in urban areas, and most cases had a history of recent contact with poultry or poultry products [5]. By 16 May 2013, 131 human cases of influenza $A\left(\mathrm{H}_{7} \mathrm{~N} 9\right)$ virus infection, in 10 provinces and municipalities in eastern China, had been reported to the World Health Organization (WHO), of which 32 had resulted in death [6]. To date there have not been any reports of sustained human-to-human transmission of the influenza $A\left(H_{7} \mathrm{~N} 9\right)$ virus, but the rapid emergence of the virus has led to significant concerns that it could in the future acquire human transmissibility and spread globally, causing the next influenza pandemic.

Rapid testing and diagnosis of possible human influenza $\mathrm{A}\left(\mathrm{H}_{7} \mathrm{~N} 9\right)$ virus infections is an important diagnostic and public health task. An accurate diagnosis will allow the timely administration of antiviral therapy
$[7,8]$ and may also enable the quarantining of infected cases to prevent further spread of the virus. Real-time PCR is now considered the gold standard laboratorybased assay for the detection of influenza virus infections due to its high sensitivity and specificity [6] and, although such assays have already been developed for the detection of influenza $A\left(\mathrm{H}_{7} \mathrm{~N} 9\right)$ virus [6], they require a high level of laboratory expertise and may not be available in all places where cases occur.

Point-of-care tests (POCTs) based on antigen detection, however, are simple to use and are designed for use in a medical clinic or outpatient setting, enabling the rapid testing of patient specimens within 15 minutes [9]. POCTs have mostly been licensed for detection of seasonal human influenza viruses, for which they generally have good specificity but low sensitivity [10]. Recently however, some POCTs have been specifically developed to utilise automated readers which have resulted in improved sensitivity. For public health purposes, it is important to determine whether the new or existing POCTs can detect the novel influenza $A\left(\mathrm{H}_{7} \mathrm{~N}_{9}\right)$ virus, particularly as previous studies have found that some POCTs had poorer sensitivity in detecting avian influenza strains compared to circulating human seasonal influenza strains [9]. If POCTs could reliably detect influenza $A\left(\mathrm{H}_{7} \mathrm{~N} 9\right)$ virus at clinically relevant levels, they would be a useful adjunct to real-time PCR in the detection of possible human cases, especially where technical resources are limited.

We evaluated six widely available POCTs that are based on detection of the nucleoprotein antigen (Table 1) for their ability to detect the avian influenza $A\left(\mathrm{H}_{7} \mathrm{~N} 9\right)$ virus $A /$ Anhui/01/2013 [5], compared with three other low pathogenic avian influenza $A\left(\mathrm{H}_{7}\right)$ viruses (A/Northern Shoveller/Egypt-EMC/1/2012, A/ Mallard/Netherlands/4/2010 and A/Mallard/Lithuania$E M C / 2 / 2010)$, two human seasonal influenza $A\left(\mathrm{H}_{3} \mathrm{~N}_{2}\right)$ (A/Sydney/506/2013 and A/Victoria/361/2011) and two influenza $A\left(\mathrm{H}_{1} \mathrm{~N}_{1}\right)$ pdmog viruses (A/Auckland/1/2009 and A/Brisbane/292/2010). 
TABLE 1

Details of influenza point-of-care tests evaluated in this study

\begin{tabular}{|l|l|l|l|l|l|l|}
\hline Point-of-care test & Manufacturer & $\begin{array}{l}\text { Specimen } \\
\text { type approved }\end{array}$ & $\begin{array}{l}\text { Proportion of virus sample } \\
\text { following addition of diluenta }\end{array}$ & Format & $\begin{array}{l}\text { Time } \\
\text { (minutes) }\end{array}$ & $\begin{array}{l}\text { Analysis of } \\
\text { result }\end{array}$ \\
\hline $\begin{array}{l}\text { SD Bioline Influenza Ag/A/B/ } \\
\text { A(H1N1)Pandemic }\end{array}$ & $\begin{array}{l}\text { Standard } \\
\text { Diagnostics, } \\
\text { Korea }\end{array}$ & $\begin{array}{l}\text { NPS, NS, NA, } \\
\text { NPA }\end{array}$ & $50 \%(\mathrm{~S}: 100 \mu \mathrm{l}+\mathrm{D}: 100 \mu \mathrm{l})$ & Test strip & $10-15$ & Eye \\
\hline $\begin{array}{l}\text { Binax Now } \\
\text { Influenza A \& B Card }\end{array}$ & $\begin{array}{l}\text { Alere, Unites } \\
\text { States }\end{array}$ & $\begin{array}{l}\text { NW, NA, NPS, } \\
\text { NS }\end{array}$ & $100 \%(\mathrm{~S}: 100 \mu \mathrm{l})$ & Card & 15 & Eye \\
\hline $\begin{array}{l}\text { Clearview Exact } \\
\text { Influenza A \& }\end{array}$ & $\begin{array}{l}\text { Inverness } \\
\text { Medical, } \\
\text { Australia }\end{array}$ & NS & $29 \%\left(\mathrm{~S}: 50 \mu \mathrm{l}^{\mathrm{b}}+\mathrm{D}: 120 \mu \mathrm{l}\right)$ & Test strip & 15 & Eye \\
\hline $\begin{array}{l}\text { BD Veritor System for rapid } \\
\text { detection of Flu A+B }\end{array}$ & $\begin{array}{l}\text { Becton, } \\
\text { Dickinson, Unites } \\
\text { States }\end{array}$ & NS, NPS & $11 \%\left(\mathrm{~S}: 50 \mu \mathrm{l}^{\mathrm{b}}+\mathrm{D}: 400 \mu \mathrm{l}\right)$ & Cartridge & 10 & $\begin{array}{l}\text { Automated } \\
\text { reader }\end{array}$ \\
\hline BD Directigen EZ Flu A+B & $\begin{array}{l}\text { Becton, } \\
\text { Dickinson, Unites } \\
\text { States }\end{array}$ & $\begin{array}{l}\text { NW, NA, NPS, } \\
\text { TS }\end{array}$ & $83 \%(\mathrm{~S}: 300 \mu \mathrm{l}+\mathrm{D}: 60 \mu \mathrm{l})$ & Cartridge & 15 & Eye \\
\hline Sofia Influenza A+B FIA & $\begin{array}{l}\text { Quidel, Unites } \\
\text { States }\end{array}$ & $\begin{array}{l}\text { NS, NPS, NPA, } \\
\text { NW }\end{array}$ & $46 \%(S: 260 \mu \mathrm{l}+$ D: 300$)$ & Cartridge & 15 & $\begin{array}{l}\text { Automated } \\
\text { reader }\end{array}$ \\
\hline
\end{tabular}

D: diluent; NA, nasal aspirate; NPA, nasopharyngeal aspirate; NPS, nasopharyngeal swab; NS, nasal swab; NW, nasal wash; S: specimen.

a Dilution of specimen in kit diluent is presented as a percentage, where volumes of specimen (S) and diluent (D) are shown in parentheses

${ }^{b}$ Because the kit is not approved for testing of wash or aspirate samples, the specimen was absorbed by the swab provided after at least a 15 second immersion in the virus sample. The volume taken up by the swab was found to be approximately $50 \mu$ l.

\section{Methods}

All viruses were cultured in Madin-Darby Canine Kidney (MDCK) cells at a low multiplicity of infection for at least one passage before testing. All viruses were harvested at near full cytopathic effect (CPE), supernatant was centrifuged at low speed to remove cell debris, and viruses were frozen at $-70^{\circ} \mathrm{C}$ prior to testing. A mean tissue culture infectious dose $50\left(\mathrm{TCID}_{50}\right)$ per $\mathrm{mL}$ was determined for each virus, based on at least three independent assays. Viruses were standardised to an infectivity titre of $1 \times 10^{6} \mathrm{TCID}_{50} / \mathrm{mL}$ and then diluted in phosphate-buffered saline (PBS) in half- $\log _{10}$ dilutions. Real-time RT-PCR analysis was conducted on each virus dilution to determine a cycle threshold $(\mathrm{Ct})$ value and RNA copy number, using an Applied Biosystems 7500 Fast cycler and the real-time RT-PCR primer and probe set recommended by the United States Centers for Disease Prevention and Control (US CDC) for the detection of influenza A matrix genes (version 4 April 2006). RNA copy number was calculated using a standard curve of RNA standards (10-fold dilutions) of known copy number prepared from a pGEMT-A/ California/7/2009 matrix plasmid using the Riboprobe In Vitro Transcription System (Promega, United States).

Each virus dilution was then tested in each POCT according to the manufacturer's instructions and a limit of detection (LOD), based on either the $\mathrm{TCID}_{50} /$ $\mathrm{mL}$ or the RNA copy number/ $\mu \mathrm{L}$, was determined. Standardising viruses by viral infectivity $\left(\mathrm{TCID}_{50} / \mathrm{mL}\right)$ is the most widely used method for the evaluation of POCTs, however it does not account for defective viral particles which may react in these antigen-detection assays. Therefore comparison of the LOD based on both $\mathrm{TCID}_{50} / \mathrm{mL}$ and RNA copy number/ $\mu \mathrm{L}$ (which accounts for both infective and defective viruses) can be informative. Half- $\log _{10}$ dilutions of influenza A/Anhui/01/2013 virus were prepared in duplicate and both sets tested with the six POCTs. The number of available test kits was not sufficient to conduct duplicate testing of the other seven viruses. The duplicate sets of influenza A/ Anhui/01/2013 virus concentrations gave highly comparable LOD data, therefore data for only the first set is presented. Four of the kits were read by eye, while two POCTs (Veritor and Sofia) utilised a mechanical reader (Table 1).

\section{Results}

Based on the $\mathrm{TCID}_{50} / \mathrm{mL}$, the LOD of five of the six POCTs for the $A / A n h u i / 01 / 2013$ influenza $A\left(\mathrm{H}_{7} \mathrm{~N} 9\right)$ virus ranged from $1 \times 10^{5}$ to $1 \times 10^{5.5} \mathrm{TCID}_{50} / \mathrm{mL}$, with the Sofia and Directigen EZ detecting virus at the lower limit. The Clearview POCT was unable to detect the influenza $A\left(\mathrm{H}_{7} \mathrm{~N} 9\right)$ virus at any of the concentrations tested ( $1 \times 10^{6} \mathrm{TCID}_{50} / \mathrm{mL}$ or lower) (Table 2 ). In comparison, the LOD of the POCTs for the other influenza $A\left(\mathrm{H}_{7}\right)$ viruses tested was generally better than that seen with the A/ Anhui/01/2013 virus, with some tests detecting virus levels as low as $1 \times 10^{2} \mathrm{TCID}_{50} / \mathrm{mL}$. Seasonal influenza $A$ viruses were also more easily detected by most POCTs 
TABLE 2

$\mathrm{TCID}_{50}$ limit of detection of the influenza point-of-care tests evaluated in this study

\begin{tabular}{|c|c|c|c|c|c|c|c|}
\hline \multirow{2}{*}{$\begin{array}{l}\text { Influenza virus origin/ } \\
\text { subtype }\end{array}$} & \multirow[b]{2}{*}{ Designation } & \multicolumn{6}{|c|}{ Limit of detection $\left(\log _{10} \mathrm{TCI}_{50} / \mathrm{mL}\right)$} \\
\hline & & SD Bioline & $\begin{array}{l}\text { Binax } \\
\text { Now }\end{array}$ & Clearview & Veritor & $\begin{array}{l}\text { Directigen } \\
\text { EZ }\end{array}$ & Sofia \\
\hline Human $\mathrm{A}\left(\mathrm{H}_{7} \mathrm{~N} 9\right)$ & A/Anhui/01/2013 & 5.5 & 5.5 & $>6^{\mathrm{a}}$ & 5.5 & 5 & 5 \\
\hline \multirow[t]{3}{*}{ Avian $\mathrm{A}\left(\mathrm{H}_{7}\right)$} & A/Northern Shoveller Egypt-EMC/1/2012 & 5 & 4 & $>6^{\mathrm{a}}$ & 4 & 4 & 3 \\
\hline & $\mathrm{A} /$ Mallard/Netherlands/4/2010 & 5 & 4 & $>6^{\mathrm{a}}$ & 4 & 4 & 2.5 \\
\hline & A/Mallard/Lithuania-EMC/2/2010 & 4 & 3 & 4.5 & 2.5 & 2.5 & 2 \\
\hline \multirow[t]{2}{*}{ Human $\mathrm{A}\left(\mathrm{H}_{1} \mathrm{~N}_{1}\right)$ pdmog } & A/Auckland/1/2009 & 4.5 & 3.5 & 5 & 3 & 3 & 2.5 \\
\hline & A/Brisbane/292/2010 & 4 & 3 & 4.5 & 3 & 2.5 & 2 \\
\hline \multirow[t]{2}{*}{ Human $\mathrm{A}\left(\mathrm{H}_{3} \mathrm{~N}_{2}\right)$} & A/Sydney/506/2013 & 5 & 4 & 5 & 4 & 4 & 3 \\
\hline & A/Victoria/361/2011 & 4 & 3.5 & 4.5 & 3 & 3 & 2.5 \\
\hline
\end{tabular}

$\mathrm{TCID}_{50}$ : tissue culture infectious dose 50.

a $>6$, the virus was not detected at any of the concentrations tested.

\section{TABLE 3}

RNA copy number and Ct value limit of detection of the influenza point-of-care tests evaluated in this study

\begin{tabular}{|c|c|c|c|c|c|c|c|c|}
\hline \multirow[b]{2}{*}{$\begin{array}{l}\text { Influenza virus } \\
\text { origin/subtype }\end{array}$} & \multirow[b]{2}{*}{ Designation } & \multicolumn{6}{|c|}{ Limit of detection (RNA copies/ $\mu \mathrm{L}$ [Ct value]) } & \multirow{2}{*}{$\begin{array}{c}\text { RNA copies/ } \\
\mu \mathrm{L}[\mathrm{Ct} \text { value] of } \\
1 \times 10^{4.5} \mathrm{TCID}_{50} / \mathrm{mL} \\
\text { concentrations }\end{array}$} \\
\hline & & SD Bioline & $\begin{array}{l}\text { Binax } \\
\text { Now }\end{array}$ & Clearview & Veritor & $\begin{array}{l}\text { Directigen } \\
\text { EZ }\end{array}$ & Sofia & \\
\hline Human $\mathrm{A}\left(\mathrm{H}_{7} \mathrm{~N} 9\right)$ & A/Anhui/01/2013 & $\begin{array}{c}5.0 \times 10^{5} \\
{[22.2]} \\
\end{array}$ & $\begin{array}{c}5.0 \times 10^{5} \\
{[22.2]} \\
\end{array}$ & $\begin{array}{l}>1.5 \times 10^{6 a} \\
{[<20.4]}\end{array}$ & $\begin{array}{c}5.0 \times 10^{5} \\
{[22.2]} \\
\end{array}$ & $\begin{array}{l}1.6 \times 10^{5} \\
{[24.0]}\end{array}$ & $\begin{array}{c}1.6 \times 10^{5} \\
{[24.0]}\end{array}$ & $\begin{array}{c}3.6 \times 10^{4} \\
{[26.2]} \\
\end{array}$ \\
\hline \multirow[t]{3}{*}{ Avian $\mathrm{A}\left(\mathrm{H}_{7}\right)$} & $\begin{array}{l}\text { A/Northern Shoveller/ } \\
\text { Egypt-EMC/1/2012 }\end{array}$ & $\begin{array}{c}2.3 \times 10^{6} \\
{[19.7]} \\
\end{array}$ & $\begin{array}{c}2.3 \times 10^{5} \\
{[23.3]} \\
\end{array}$ & $\begin{array}{l}22.9 \times 10^{7 \mathrm{a}} \\
{[\ll 15.8]}\end{array}$ & $\begin{array}{c}2.3 \times 10^{5} \\
{[23.3]}\end{array}$ & $\begin{array}{l}2.3 \times 10^{5} \\
{[23.3]}\end{array}$ & $\begin{array}{c}2.1 \times 10^{4} \\
{[27.2]}\end{array}$ & $\begin{array}{l}4.1 \times 10^{5} \\
{[22.5]}\end{array}$ \\
\hline & $\begin{array}{l}\text { A/Mallard/ } \\
\text { Netherlands/4/2010 }\end{array}$ & $\begin{array}{l}6.3 \times 10^{5} \\
{[21.6]} \\
\end{array}$ & $\begin{array}{c}5.6 \times 10^{4} \\
{[25.7]} \\
\end{array}$ & $\begin{array}{c}>1.1 \times 10^{7 \mathrm{a}} \\
{[<17.2]} \\
\end{array}$ & $\begin{array}{c}5.6 \times 10^{4} \\
{[25.7]} \\
\end{array}$ & $\begin{array}{c}5.6 \times 10^{4} \\
{[25.7]} \\
\end{array}$ & $\begin{array}{c}6.0 \times 10^{2} \\
{[31.8]} \\
\end{array}$ & $\begin{array}{l}1.3 \times 10^{5} \\
{[24.2]} \\
\end{array}$ \\
\hline & $\begin{array}{l}\text { A/Mallard/ } \\
\text { Lithuania-EMC/2/2010 }\end{array}$ & $\begin{array}{c}7.4 \times 10^{5} \\
{[21.7]}\end{array}$ & $\begin{array}{c}6.6 \times 10^{4} \\
{[25.5]}\end{array}$ & $\begin{array}{l}1.5 \times 10^{6} \\
{[20.5]}\end{array}$ & $\begin{array}{c}1.5 \times 10^{4} \\
{[27.6]}\end{array}$ & $\begin{array}{l}1.5 \times 10^{4} \\
{[27.6]}\end{array}$ & $\begin{array}{c}8.8 \times 10^{3} \\
{[28.6]}\end{array}$ & $\begin{array}{l}1.5 \times 10^{6} \\
{[20.5]}\end{array}$ \\
\hline \multirow[t]{2}{*}{$\begin{array}{l}\text { Human } \mathrm{A}\left(\mathrm{H}_{1} \mathrm{~N}_{1}\right) \\
\text { pdmog }\end{array}$} & A/Auckland/1/2009 & $\begin{array}{l}1.2 \times 10^{6} \\
{[20.8]} \\
\end{array}$ & $\begin{array}{l}8.9 \times 10^{4} \\
{[25.0]} \\
\end{array}$ & $\begin{array}{c}4.5 \times 10^{6} \\
{[18.8]} \\
\end{array}$ & $\begin{array}{c}5.6 \times 10^{4} \\
{[25.3]} \\
\end{array}$ & $\begin{array}{c}5.6 \times 10^{4} \\
{[25.3]} \\
\end{array}$ & $\begin{array}{c}4.6 \times 10^{3} \\
{[28.2]} \\
\end{array}$ & $\begin{array}{l}1.2 \times 10^{6} \\
{[20.8]} \\
\end{array}$ \\
\hline & A/Brisbane/292/2010 & $\begin{array}{c}2.7 \times 10^{6} \\
{[19.5]} \\
\end{array}$ & $\begin{array}{c}3.2 \times 10^{5} \\
{[23.0]}\end{array}$ & $\begin{array}{c}4.5 \times 10^{6} \\
{[19.0]}\end{array}$ & $\begin{array}{l}3.2 \times 10^{5} \\
{[23.0]}\end{array}$ & $\begin{array}{c}5.7 \times 10^{4} \\
{[25.5]} \\
\end{array}$ & $\begin{array}{c}1.3 \times 10^{4} \\
{[26.5]} \\
\end{array}$ & $\begin{array}{c}4.5 \times 10^{6} \\
{[19.0]} \\
\end{array}$ \\
\hline \multirow[t]{2}{*}{ Human $\mathrm{A}\left(\mathrm{H}_{3} \mathrm{~N}_{2}\right)$} & A/Sydney/506/2013 & $\begin{array}{c}2.6 \times 10^{6} \\
{[19.7]} \\
\end{array}$ & $\begin{array}{c}2.2 \times 10^{5} \\
{[23.5]} \\
\end{array}$ & $\begin{array}{c}2.6 \times 10^{6} \\
{[19.7]} \\
\end{array}$ & $\begin{array}{c}2.2 \times 10^{5} \\
{[23.5]} \\
\end{array}$ & $\begin{array}{c}2.2 \times 10^{5} \\
{[23.5]} \\
\end{array}$ & $\begin{array}{c}6.3 \times 10^{3} \\
{[26.8]} \\
\end{array}$ & $\begin{array}{l}4.9 \times 10^{5} \\
{[22.2]} \\
\end{array}$ \\
\hline & A/Victoria/361/2011 & $\begin{array}{c}5.9 \times 10^{5} \\
{[21.9]} \\
\end{array}$ & $\begin{array}{l}1.1 \times 10^{5} \\
{[24.3]} \\
\end{array}$ & $\begin{array}{c}1.1 \times 10^{6} \\
{[21.0]}\end{array}$ & $\begin{array}{c}5.7 \times 10^{4} \\
{[26.0]} \\
\end{array}$ & $\begin{array}{c}5.7 \times 10^{4} \\
{[26.0]} \\
\end{array}$ & $\begin{array}{c}7.9 \times 10^{3} \\
{[27.8]} \\
\end{array}$ & $\begin{array}{l}1.1 \times 10^{6} \\
{[21.0]}\end{array}$ \\
\hline
\end{tabular}

Ct: cycle threshold; $\mathrm{TCID}_{50}$ : tissue culture infectious dose 50 .

${ }^{a}$ The virus was not detected at any of the concentrations tested. 


\section{FIGURE}

Mean Ct limit of detection for influenza A/Anhui/01/2013 in point-of-care tests compared with $\mathrm{Ct}$ values reported for four influenza $\mathrm{A}(\mathrm{H} 7 \mathrm{~N} 9)$ cases confirmed by RT-PCR

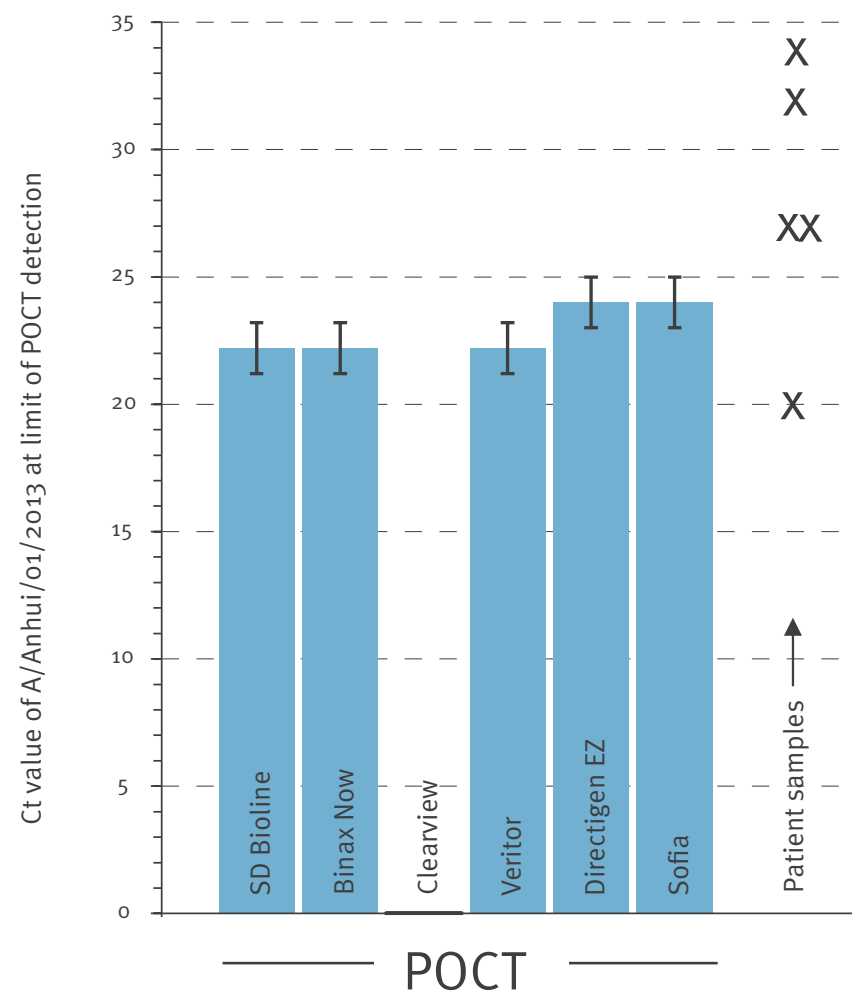

Ct: cycle threshold; $\mathrm{TCID}_{50}$ : tissue culture infectious dose 50; POCT: point-of-care test.

The $\mathrm{Ct}$ values of the $\mathrm{A} / \mathrm{Anhui} / 01 / 2013$ concentrations containing $1 \times 10^{6}, 1 \times 10^{5.5}, 1 \times 10^{5}, 1 \times 10^{4.5} \mathrm{TCID}_{50} / \mathrm{mL}$ were $20.4,22.2,24.0$ and 26.2 respectively, while the RNA copy number was $1.5 \times 10^{6} / \mu \mathrm{L}$, $5.0 \times 10^{5} / \mu \mathrm{L}, 1.6 \times 10^{5} / \mu \mathrm{L}$, and $3.6 \times 10^{4} / \mu \mathrm{L}$ respectively. Error bars indicate the standard deviation based on triplicate real-time RT-PCR analysis of the virus concentration at the POCT limit of detection. Influenza A matrix gene $C t$ values for the cases were $27,32-34,20$ and 27 for the four patients, respectively, and were taken from the published article by Chen et al. [11]. RT-PCR efficiencies and therefore $\mathrm{Ct}$ values may differ slightly between the assay used here and that used by Chen et al. Because the Clearview POCT did not detect the influenza A/Anhui/01/2013 virus at any concentration tested, a Ct value of the limit of detection could not be determined for this kit.

than the influenza $A\left(\mathrm{H}_{7} \mathrm{~N} 9\right)$ virus, with the Sofia kit performing best: LOD ranging from $1 \times 10^{2}$ to $1 \times 10^{3} \mathrm{TCID}_{50} /$ $m L$ for the human influenza $A\left(H_{3} N_{2}\right)$ and $A\left(H_{1} N_{1}\right)$ pdmog viruses.

Comparison of POCT LODs based on RNA copy number/ $\mu \mathrm{L}$ showed similar results to those based on $\mathrm{TCID}_{50} / \mathrm{mL}$ for four of the kits (Binax Now, Clearview, Veritor and Sofia). These POCTs were less sensitive for the detection of the influenza $\mathrm{A}\left(\mathrm{H}_{7} \mathrm{~N} 9\right)$ virus compared to the seasonal or other influenza $\mathrm{A}\left(\mathrm{H}_{7}\right)$ viruses (Table 3 ). However, for the SD Bioline and the Directigen EZ tests, comparison of the LODs based on RNA copy number/ $\mu \mathrm{L}$ showed that influenza $\mathrm{A}\left(\mathrm{H}_{7} \mathrm{~N} 9\right)$ was detected at a similar sensitivity to the other viruses (Table 3 ).

LODs based on RNA copy number/ $\mu \mathrm{L}$ or $\mathrm{Ct}$ also allowed an estimate of the expected performance of the POCTs in detecting influenza $\mathrm{A}\left(\mathrm{H}_{7} \mathrm{~N} 9\right)$ virus in clinical samples (Figure). Comparison of the published $\mathrm{Ct}$ values of clinical samples from patients with confirmed influenza $\mathrm{A}\left(\mathrm{H}_{7} \mathrm{~N} 9\right)$ infection [11] suggested that five of the six POCTS would have detected only one of the four influenza $\mathrm{A}\left(\mathrm{H}_{7} \mathrm{~N}\right.$ 9)-positive clinical specimens, with the other three specimens being outside the LOD of these assays (Figure).

\section{Discussion}

For all viruses tested, the Sofia POCT, which uses an automated reader, had the highest sensitivity. The BD Veritor test, which also uses an automated reader, had comparable sensitivity to the BD Directigen EZ and the Binax Now tests, both of which are read by eye. The Clearview and SD Bioline POCTs demonstrated the poorest sensitivity.

It is important to note that both the Clearview and the BD Veritor tests are only approved for analysis of swab specimens, therefore the test method used here may not have been appropriate. Similarly, all POCT assays may perform better using a particular specimen type, which was not tested here. The collection of the virus sample used for the Clearview and the BD Veritor POCTs (dipping the swab into liquid and waiting at least 15 seconds for absorption) resulted in a sample volume of approximately $50 \mu \mathrm{L}$ which, when combined with the recommended diluent volume, resulted in the lowest concentrations of virus used in this evaluation (Table 1).

Other limitations of this study include the use of only a single influenza $\mathrm{A}\left(\mathrm{H}_{7} \mathrm{~N} 9\right)$ isolate $\mathrm{A} / \mathrm{Anhui} / 01 / 2013$ (although this virus is genetically closely related to other human influenza $A\left(\mathrm{H}_{7} \mathrm{~N} 9\right)$ viruses for which sequences have been reported) and the fact that clinical specimens were not available for analysis. It is also important to note that these POCTs have not been primarily designed or licensed to detect influenza $A\left(\mathrm{H}_{7} \mathrm{~N}_{9}\right)$ viruses or other avian-derived viruses.

Nevertheless, this study does demonstrate that the sensitivity of at least four of the six evaluated POCTs is lower for the novel influenza $\mathrm{A}\left(\mathrm{H}_{7} \mathrm{~N} 9\right)$ virus than for seasonal influenza viruses and the other avian influenza $\mathrm{A}\left(\mathrm{H}_{7}\right)$ viruses tested. Comparison with published $\mathrm{Ct}$ values for clinical specimens from influenza $A\left(\mathrm{H}_{7} \mathrm{~N} 9\right)$ patients suggested that these POCTs may not detect the majority of influenza $\mathrm{A}\left(\mathrm{H}_{7} \mathrm{~N} 9\right)$ cases, particularly if samples are taken late in the course of disease. Therefore RT-PCR remains the diagnostic test of choice for the testing of suspected influenza $\mathrm{A}\left(\mathrm{H}_{7} \mathrm{~N} 9\right)$ influenza cases. 


\section{Acknowledgements}

The authors are grateful to Dr Yuelong Shu and Dr Dayan Wang, WHO Collaborating Centre for Reference and Research on Influenza, Chinese Center for Disease Control and Prevention, Beijing, China, for providing the A/ Anhui/1/2013 $A\left(\mathrm{H}_{7} \mathrm{~N} 9\right)$ virus. We are grateful to Heidi Peck, WHO Collaborating Centre for Reference and Research on Influenza, Melbourne, for preparing the plasmid used for RNA quantitation. The Melbourne WHO Collaborating Centre for Reference and Research on Influenza is supported by the Australian Government Department of Health and Ageing. RF was financed through NIAID-NIH contract HHSN266200700010C.

\section{Conflict of interest}

None declared

\section{Authors' contributions}

Designed the study: $C B, I B, A H$. Analysed and interpreted the data: $C B, R F, A K$, IB and $A H$. Drafted the article: $C B$ and $A H$. Revised the article: $C B, R F, A K, I B$ and $A H$.

\section{References}

1. World Health Organization (WHO). Influenza at the HumanAnimal interface. Summary and assessment as of 26 April 2013.Geneva: WHO. [Accessed: 4 May 2013]. Available from: http://www.who.int/influenza/human_animal_interface/ Influenza Summary IRA HA interface 26Apr13.pdf

2. Fouchier RA, Schneeberger PM, Rozendaal FW, Broekman JM, Kemink SA, Munster V, et al. Avian influenza A virus $\left(\mathrm{H}_{7} \mathrm{~N} 7\right)$ associated with human conjunctivitis and a fatal case of acute respiratory distress syndrome. Proc Natl Acad Sci U S A. 2004;101(5):1356-61 http://dx.doi.org/10.1073/pnas.0308352100 PMid:14745020 PMCid:337057

3. Centers for Disease Control and Prevention (CDC). Notes from the field: Highly pathogenic avian influenza $A\left(\mathrm{H}_{7} \mathrm{~N}_{3}\right)$ virus infection in two poultry workers--Jalisco, Mexico, July 2012. MMWR Morb Mortal Wkly Rep. 2012;61(36):726-7. PMid:22971746

4. Belser JA, Bridges CB, Katz JM, Tumpey TM. Past, present, and possible future human infection with influenza virus $A$ subtype H7. Emerg Infect Dis. 2009;15(6):859-65. http://dx.doi.org/10.3201/eid1506.090072 PMid:19523282 PMCid:2727350

5. Gao R, Cao B, Hu Y, Feng Z, Wang D, Hu W, et al. Human Infection with a Novel Avian-Origin Influenza A ( $\mathrm{H} 7 \mathrm{~N} 9)$ Virus. N Engl J Med. 2013;368(20):1888-97.

http://dx.doi.org/10.1056/NEJMoa1304459 PMid:23577628

6. World Health Organization (WHO). Number of confirmed human cases of avian influenza $A\left(\mathrm{H}_{7} \mathrm{~N} 9\right)$ reported to WHO. Geneva: WHO. [Accessed: 16 May 2013]. Available from: http://www. who.int/influenza/human_animal_interface/influenza_h7ng/ Data_Reports/en/index.html

7. Moscona A. Neuraminidase inhibitors for influenza. N Engl I Med. 2005;353(13):1363-73.

http://dx.doi.org/10.1056/NEJMra050740 PMid:16192481

8. Aoki FY, Macleod MD, Paggiaro P, Carewicz O, El Sawy A, Wat C, et al. Early administration of oral oseltamivir increases the benifits of influenza treatment. J Antimicrob Chemother. 2003:51(1):123-9. http://dx.doi.org/10.1093/jac/dkgoo7 PMid:12493796

9. Sakai-Tagawa Y, Ozawa M, Tamura D, Le M, Nidom CA, Sugaya $\mathrm{N}$, et al. Sensitivity of influenza rapid diagnostic tests to $\mathrm{H}_{5} \mathrm{~N}_{1}$ and 2009 pandemic $\mathrm{H}_{1} \mathrm{~N}_{1}$ viruses. I Clin Microbiol. 2010;48(8):2872-7. http://dx.doi.org/10.1128/JCM.00439-10 PMid:20554831 PMCid:2916590

10. Hurt AC, Alexander R, Hibbert J, Deed N, Barr IG. Performance of six influenza rapid tests in detecting human influenza in clinical specimens. J Clin Virol. 2007;39(2):132-5. http://dx.doi.org/10.1016/j.jcv.2007.03.002 PMid:17452000

11. Chen Y, Liang W, Yang S, Wu N, Gao H, Sheng J, et al. Human infections with the emerging avian influenza $\mathrm{A} \mathrm{H} 7 \mathrm{~N}$ 9 virus from wet market poultry: clinical analysis and characterisation of viral genome. Lancet. 2013; 25 April: pii: So1406736(13)60903-4.

http://dx.doi.org/10.1016/S0140-6736(13)60903-4 